\title{
The Differences of Emphasis Among Teachers, Students and Parents Concerning School Climate
}

\author{
Rahmania Utari \\ Universitas Negeri Yogyakarta \\ Yogyakarta, Indonesia \\ rahmaniautari@uny.ac.id
}

\author{
Mada Sutapa \\ madasutapa@gmail.com
}

\begin{abstract}
This paper is based on the research which is conducted at Gunungkidul regency, Indonesia. The final objective of this research is to create web-based school climate measurement instrument. This research uses design and development method, which was the combination of research and development $(R \& D)$ and design and development (D \& D). The research had spent one year from two planned years. At the first year, the target of the research is to create school climate measurement instrument substance. Meanwhile, the second year target is web-based school climate measurement information system. This paper describes the earlier stage of the research that presents suggestions and opinions from stakeholder concerning school climate measurement. The data was collected through FGD with the collaboration of teachers, headmaster, education department staff, students, and parents. The FGD revealed some differences of emphasis on school climate aspect among the participants. Therefore the school climate survey will be given to three parties adapting their point of view on school climate and their experiences in perceiving school climate. Each instrument will be adjusted to each group of respondent's authority, their role at school, and their experiences as schools stakeholder. The other FGD results show how different of the problem concerning school climate between Indonesia and other countries especially developed ones. Lastly, in general the FGD participants agree that school climate survey is needed for school improvement, and is expected that public can access the survey and its result.
\end{abstract}

Keywords—school climate, school survey

\section{INTRODUCTION}

In the last 30 years, researchers of education field had identified the characteristics of effective school. As in [1], effective schools characteristics are: (1) high teacher's orientation and expectation of achievement (2) strong leadership, (3) consensus and cohesion among school staff, (4) high quality curriculum, (5) learning opportunity, (6) conducive school climate and security (7) the potency of evaluating ability (8) parent involvement 9) learning climate, (10) effective time management in classroom (11) structured teaching, (12) independent learning encouragement, (13) adaptive learning, (14) feedback. Referring to the elaboration above, it can be concluded that the expectation to create effective learning relies on human resource ability, facility, and institution climate.

Reference [2] described organization climate as measured quality, which is identified from perception of people who work together at the same place. This thing influences behavior of organization members. This thing is also applied at school institution with considering school environment aspect, which has specific characteristic. School climate is the reflection of school members' interaction. This interaction covers inside and outside-class interaction. [3] School climate effects on school members behavior and contributes to school achievement.

As mentioned in [4], it is recommended the headmaster to interact with school climate. This interaction will build school structure and helps the headmaster to focus on school objectives. This thing will not happen if the headmaster cannot detect his school climate.

School climate can be detected through some types of measurement. As in [5], it includes comprehensive surveys, community scales that recognize the community members' opinion, and assessment of school current strengths and needs, and lastly he mentioned process assessment that record what school staff has done and has not done during the school climate improvement process. Other researchers argue that school climate measurement can be conducted with two ways [6] It was explained, that the first is by analyzing secondary data (the level of student absence, teacher's delay, drop out level, and the observation of situation). The second way is by measuring using instrument such as questionnaire. In developed countries, this measurement is common. Meanwhile, in developing countries, it is still rare. This case happens because of the lack of awareness of school climate importance. In addition, there is no instrument, which helps schools to detect their atmosphere. The sufficient attention must be given to school climate [7] because there is correlation between student's aggressiveness and student's perception towards their school climate. School with positive school climate enjoys lesser behavior problems, increased academic achievement, stronger self-esteem on student, and greater commitment to school. [8]

Based on the explanation above, research of school climate becomes a need. In recent days, school climate survey is common thing in developed countries. Unfortunately, for developing country like Indonesia, this survey is a rare thing and even it may still luxurious because of the lack of study about school climate and insufficient instrument. Therefore, this research is conducted with the objective to create comprehensive school climate profile. This paper will evaluate data, which had been gotten as the result of needs assessment, which was conducted together with stakeholders. Then, this 
data will be analyzed and will be developed as school climate online survey content in high school level.

\section{LITERATURE REVIEW}

\section{A. School Climate}

School climate is a part of school process. [9] The researchers and practitioners use alternately the term of school climate with other names such as atmosphere or feeling about the school. School climate refers to the quality and character in the school living. [10] It based on patterns of how school life that people has experienced. There are complex aspect involving students, teachers, and parents on school climate, from norms, values and expectations to physically safe.

There has been significant interest on school climate, since it is believed that it has meaningful relation with school violence [11], and not only lead to some typical school goals such as academic achievement, it also promotes multiple developmental goals. [12]

Establishing school climate could not only be relied on teacher and students, family should be involved as well. Research has showed that the interaction effect of family, gender and family residence is significant for perceptions of student's cohesiveness and how they accomplish the school task and how they do in learning process. [13]

There are numerous factors that was believed could improve school climate. One thing for sure, the elements that comprise a school's climate can be very complex. Many researchers mentioned as the most influential factors of school climate as follow [14]:

1) Quantity and quality of adults and students interaction

2) Students' and teachers' perception of their school environment

3) Environmental factors such as building and material things

4) Academic performance

5) Feelings of safeness and school size

6) Feelings of trust and respect among people at school

Meanwhile [15] proposed four dimensions in school climate: teaching and learning, relationship, safety and physical environment. Reference resumes that the school environment has three dimensions: physical, school structure, and socio-education environment. When it comes to school structure, it refers to school size, type of curriculum, architectural elements. School structure is known as the least flexible features of the school as an organization. Ultimately, it can be concluded that there are three pillars to establish school climate, not just social dimension and academic domain, but also physical

\section{B. School Climate Measurement}

The theoretical framework of school climate measurement has been influenced by social-ecological perspective because it involves individual's perceptions of the social environment especially social transaction. [16] Therefore, many school climate surveys are not only addressed to teacher but also students, with the student result that mostly to be less positive than teacher perceptions.
The survey of school climate mostly developed based on responsiveness-demandingness, or support-structure, and the dimension of school discipline and school climate. Study of school climate survey in Delaware assesses social support and structure included subscales: fairness of rules, school safety, and student conduct problems and liking of schools.

To generate comprehensive profile of school climate, the subscales can cover the areas of achievement motivation, fairness, order and discipline, parent involvement, sharing of resources, student interpersonal and student-teacher relationships. Furthermore, the issue may be more extended to such as safety, school services, student activities and teacherprincipal interaction.

It is recommended that survey should be particularly useful to evaluate school and to design prevention and intervention programs designed to improve the interaction between teacher and student and enhance school safety, fairness of school rules and student liking school.

Measuring school climate can be very depending on the school environment. For instance, in Italy where there is no validated standardized instrument of school climate measurement, the development on the first stage was adopting the National School Climate Council of New York. [17] Then the questionnaire was modified to adapt it with school situation around Italy. The questionnaire development started from investigates through focus group discussion involving parents, teachers and staff.

Learning from best practice in Colorado [18], it is suggested to use multiple measures when possible. Furthermore, there are several key questions to ask in the process of school climate survey development. First of all is what component will be measured. The next step will include how can the component be integrated into survey, how will the survey be administered, how will data be used to be followed up into action, and how the result will be communicated to the stakeholders.

\section{RESEARCH METHODS}

The method of this research is Design and Development Research (DDR). This method is chosen because it is appropriate to create a new procedure, technique, and tools, which are based on specific analysis. [19] Reference [20] limits the definition of DDR as a research, which is conducted in the context of developing a product, a new program, or product/program amelioration.

DDR method is the combination of Research \& Development (R\&D) and Design \& Development (D\&D). The other names of DDR are development research, design case, design-based research, formative research, and design research:

The steps of this research are as follows:

- Identifying background problem

- Explaining objectives

- Designing and developing artefact (product)

- Testing product

- Evaluating experiment result

- Communicating the result 
The research will be conducted in 2 cycles. At this time, the research has reached first cycle especially in the step of designing and developing the instrument.

The research is still ongoing. The steps that have been done are as follows:

- Reviewing relevant literature to identify the key aspects of school climate and possible indicators. There are three areas that would be covered in this research: academic, facilities, and social dimension.

- Conducting need assessment by involving the elements of education department, school supervisors, headmasters, teachers, and parents (conducted using focus group discussion)

- Reviewing the result of needs assessment and combining it with school climate theory to be developed into instrument item.

- Arranging feature specification or constraint that will be designed in information system.

Focus Group Discussion (FGD) method is chosen because it is expected to be able to identify suggestion and problem around school climate. According to [21], school climate measurement tools should describe comprehensive result. This result can be achieved if school climate measurement involves all potential stakeholders. Therefore, suggestion from stakeholders is extremely needed in order that those tools will meet their need.

FGD is conducted in 3 separated groups. The first FGD involved the elements of education department of Gunungkidul regency, high school supervisors, headmasters, and teachers. The second FGD is conducted with students, and the third FGD is conducted with students' parents. The number of participant in first session FGD is 30. Meanwhile, the second session and third session involve 20 people each.

The processes conducted in FGD are as follows:

- Preface and introduction, mostly used to describe FGD objectives, including researcher background and why the audience is involved.

- Asking FGD participant to fill in the biodata and answer material apperception.

- Explaining FGD process that will be conducted.

- Explaining FGD facility such as worksheet to guide the discussion.

- Recording and noting the FGD process.

The main questions which are discussed at first session FGD with education department staff, school supervisors, headmasters, and teachers are as follows:

- What are domains that should be the concern in creating school climate?

- Is there any special priority amongst mentioned domains and sub-domains?

- Who needs to be involved in school climate measurement?

- Who gets most benefit from the result of school climate measurement?

- Does the school climate measurement result have certain confidentiality level?
- Does it need to know another school's climate?

- Who needs to be granted the rights to access school climate data?

- How is the school support in conducting online survey?

- How many frequency of survey in a year? When is the right time to fill in online school climate survey?

The questions in second session FGD that is attended by student are little bit different compared to that of first session FGD. The questions are as follows:

- What is aspect, which is assumed by student to describe school climate?

- Is there any significant aspect in creating school climate?

- What is the most frequent problem in interaction at school?

- What is the most frequent problem in learning process?

- What is the hope addressed to school concerning school facility?

- Can the student access the Internet easily?

- How many frequency of survey in a year? When is the right time for student to fill it in?

For FGD session with parents, the questions are as follows:

- What indicator makes parents assume that a school has positive climate?

- What is parents' priority in measuring school climate?

- What is the element that needs to be involved in measuring school climate?

- What does the parents expect from the result of school climate survey?

- Have most parents been familiar with Internet and website?

- Is it easy for parent to access the Internet?

- How many frequency of survey in a year. When is the right time for student to fill it in?

\section{RESULT AND DisCUSSION}

The FGD participants have various opinions. It is proven that FGD, as a strategy to group people from almost-similar background or experience, can summarize various opinions. From the FGD, the researchers get additional values in the form of information concerning Gunungkidul regency society especially their opinion about education. In addition, the researcher also gets the information about obstacle, which causes the lack of interaction between teacher and student or amongst teachers.

Gunungkidul regency is located in Special Region of Yogyakarta, located $547 \mathrm{~km}$ from Indonesian capital, Jakarta. This regency has mountainous area and is well known as infertile area. The poverty level in Gunungkidul regency is the highest amongst other regencies in Special Region of Yogyakarta. However, the life expectancy is quite good.

One condition figured in FGD is that almost more than a half of teachers and headmaster are commuters. Most of them live outside Gunungkidul regency. The distance between their homes and school can be more than 20 kilometers. Because of this long distance, some teachers feel tired at school. They 
decide to spend the short time at school because it spends a lot of time to go home too.

As mentioned by the head of Gunungkidul regency education department, students and parents still need guidance so that they have aimed orientation in education. So, it can be said that academic climate has not yet been strongly formed both at school and at home.

In general, FGD participants agree that school climate needs to be formed. If they let school climate form itself naturally, there will be situation, which is out of expectation. On the first FGD, four out of 27 people believe that schools do not need to measure school climate specifically. These people feel that headmaster can identify school climate automatically so it is unnecessary to conduct a survey. All FGD participants, however, believe that measuring school climate brings big benefits.

The benefits identified from headmaster/teacher's opinion are: (1) schools have tool to detect school condition (2) schools are able to plan appropriate intervention (3) schools get feedback (4) schools can increase their learning quality. Therefore, the one who gets the most benefit is the school itself. Society and the government, however, can still get benefit from the publication of school climate measurement result. Parents believe the same thing. But, these parents emphasize the benefit towards student candidate. Interesting thing also comes from the students. They are happy to be involved in school climate survey. They believe that their participation will support their school advancement. Furthermore, they think that they have right to give suggestion for school. This information system will accommodate their aspiration concerning their school.

From the point of view of participants of first FGD, it can be concluded that the participants emphasize academic dimension. School supervisors, headmasters, and education department elements agree that there are several important things in creating school climate. These things are as follows:

1) Academic domain:

a) Student seat arrangement

b) The existence of learning group

c) Extracurricular activity which is relevant to character building

d) The way teachers motivate students

e) Academic norm

f) The working ethos of teacher and staff

g) Reward for those who have good achievement

h) Discipline sample from teacher at class

i) Learning process, which stimulates reading interest.

j) Students' learning motivation

k) Independent learning

l) Punishment system

m) IT literation for school members

n) Support and involvement of industry towards the curriculum development and implementation

o) Integration of soft skill in learning

p) Learning time management q) Method variation and the guidance of outsideclass room learning.

2) Social domain:

a) Competition climate

b) School members' interaction pattern (studentstudent, student-teacher, teacher-teacher)

c) Tolerance

d) Social status difference

e) Openness in peer group

f) Cooperation with colleague

g) Sympathy amongst students

h) Students' respect towards teachers/staff

3) Facility domain/physical domain

a. Coolness of school area

b. The completeness of practice tool/infrastructure

c. School location

d. The completeness of supportive tools (electricity, water, and communication)

e. School security

f. School garden and gazebo

g. The display of activities and information

h. The color of school paint.

i. Room ventilation

j. Parking lot

k. School clinic

l. Library

m. Classroom display

n. Classroom area

o. The concord of the number of table and the number of the student.

Compared to the opinion of students and parents, it seems that the opinion above is quite similar. However, there is different emphasis and interestingly there is new issue in school climate study. This issue is that the role of IT in creating school climate is quite important. This issue emerges at FGD, which involves supervisors, teachers, headmaster, and students. The demand of IT-based learning or learning which utilizes IT makes the need of skill and Internet facility increases.

Nevertheless, students claim that IT has significant effect on their interaction at school. Bullying even happens on internet-based social media sometimes. Cyber bullying uses technology or social media as a tool to bully. Research found that the highest frequently type of bully is verbal bullying, closely followed by physical bullying. [22]

As mentioned above, there is quite different emphasis amongst three stakeholders. In academic domain, students emphasize truancy case, students who sleep during class, the ineffective learning time, monotonous teachers, teacher with lack of material mastery, the use of cellphone at school, inappropriate use of internet/computer facility, and the lack of understanding of less structured learning and material because the students do not have textbook. This findings are strengthening other research evidences that indicate students in well-managed classroom are tend to behave better, therefore many suggestions from school psychologist that promote supportive school climate with the focus on helping teachers to implement proper classroom management strategies. [23] 
Meanwhile, for parents who do not know the learning process directly, the indicator of good learning climate is described in simpler way. For parents, the most important thing is the absence of ineffective learning time. Letting ineffective learning time exist makes the school climate look bad. Other important things, according to parents, are the socialization of school regulation and the communication between parents and teachers. Parents believe that the communication with teachers is important because they want to know how far their children can keep up with learning process. They also want to prevent worse things concerning their children's learning improvement In addition, parents feel that it is necessary to plant a dream in their children for example what would they do and be like in the future. However, FGD participants consider that the more important thing is to push children to identify their potency so that they can arrange a dream, which is relevant to their ability. Concerning this issue, parents' role is divided into two domains [24], there are how high their expectation of their children is and how the parents can be supportive towards their children. Therefore, parents should be able to combine the tight discipline and emotional support for their children.

When it comes to social aspect, students feel that the most common issues in interaction dynamics at school at Gunungkidul regency are the isolated students and the existence of exclusive peer group. According to student, it is important to measure this social situation because this situation concerns learning comfort. It is admitted that bullying happens not only at school, but also on social media. The frequency of reported bullying case, however, is not too worrying. Concerning bullying, the suggested survey to collect data is by asking students to observe bullying or physical abuse which is experienced by their friend. [24]

On facility aspect, students and parents have different emphasis compared to that of teachers and headmaster. Bathroom cleanness is very important thing to support teaching-learning process. The existence of changing room is still an issue for female student. In addition, students feel that the use of LCD projector will make learning process more interesting. Unfortunately, the use of LCD projector is not optimal. Concerning academic, the support facility such as wifi still have problem whereas most teachers encourage students to use Internet as learning source. The lack of area such as parking lot or schoolyard matters student too. Students also feel that renovation of school building spends a lot of time so that it disturbs learning comfort. The last, students hope that the library will add its collection to increase students' reading interest.

The discussion also talks about the openness of school climate information toward public. All participants agree that the public has a right to know their school climate. However, it needs specific information constrain to prevent negative social effect. The discussion participants believe that school website and school announcement board are popular inexpensive media.

All FGD participants agree that those who get most benefit from the result of school climate measurement are school element, parents, the government, and the general public. The participants from vocational school also mention the industry. Concerning the government especially the local government, participants from parents element say that school climate building is influenced by the condition of their regency. For example, parents allow their children to ride motorbike although their children do not have the driving license. Along with parents, schools also permit students to ride motorbike because of limited public transportation at Gunungkidul regency. Parents let their underage children ride motorbike and it seems that parents do not have another choice. To decrease the risk of road accident, parents check mirror on their children motorbike and safety gear like helmet. This case needs local government attention. In addition to road accident, giving motorbike to children makes the chance for unhealthy social intercourse since children feel that they are not constrained by their parents.

The next is about online information system. All teachers and headmasters say that schools have got Internet facility but some of them are still limited. The existence of wi-fi and IT laboratory has helped students and teachers to access the Internet. Unfortunately, the condition of completeness and sufficiency amongst schools is still various. The discussion amongst parents reveals that most parents have been familiar with Internet. However, Internet access has not yet been spread evenly. In addition, there are a lot of parents who have not been used to the Internet utilization. Therefore, on the survey for parents, it is suggested to use both manual survey and online survey.

Concerning the time to fill in climate school survey, all elements agree that the right time is at the end of a semester. Therefore, the frequency is twice a year. Parents believe that the correct time to fill in the survey is near the school report distribution or at school report distribution. Teachers, headmasters, and students declare the same opinion.

Based on the explanation above, the development of school climate measurement instrument needs to consider the need and point of view of each stakeholder. For example, the point of view of students and parents is different compared to the point of view of teachers and headmaster. These points of view, however, are not contradictive. School climate measurement is close to perception of each stakeholder. Therefore, the instrument needs to accommodate the need and limitation of respondent in measuring school climate.

Another thing depicted on the result of FGD is that all stakeholders focus more on academic domain. It is a proper thing since the core-business of school is to hold an education.

\section{CONCLUSION}

Lastly, it can be concluded that:

1) In general, there are a lot of similarities among teachers, principal, students and parent in the way they view the indicators of school climate. However, each group were weighting different points as they have different experiences in perceiving the school climate. 
2) The instrument of school climate survey will be given to three parties. They are teacher/headmaster, student, and parents. Each content will ask the respondent to measure school climate on academic, facility, and social domains. Although the essence is the same, the detail of the question will be adjusted to authority, job, and experience of each stakeholder element.

3) The FGD result shows that compared to other countries, the problem concerning school climate in Indonesia is not similar. The developing country like Indonesia still faces basic issues like truancy and bad sanitation. Therefore, school climate survey in developing countries cannot completely adapt the survey models from developed countries.

4) FGD participants assume that school climate survey is important thing for school improvement. School climate survey is also a tool to get them involved in evaluating the schools. In general, the survey result is expected to be seen by public. This survey is also expected to be held twice a year at the end of each semester. Special for parents, the survey can be done in two ways. They are manual survey and online survey.

\section{ACKNOWLEDGMENT}

This work is funded by The Ministry of Higher Education and Research of Indonesia. The researcher would like to thank to The Head of The Department of Education and Sport who has supported this research. The researcher would also like to thank to teachers, headmasters, supervisors, and the staff at Gunungkidul Department of Education and Sport office. Credit also goes to parents and students of high schools and vocational schools in Gunungkidul regency who enthusiastically participated in the FGD. The researcher would also like to express special thanks to the headmaster of Wonosari 2 State High School who has helped to facilitate the FGD along with students and parents.

\section{REFERENCES}

[1] P. Sammons and L. Bakkum, "Effective Schools, Equity Teacher Effectiveness: A Review to The Literature," Journal Profesorado ,vol 15, No 3, pp. 9-26, December 2011.

[2] G. Celal and G.B. Gulenay, "The Principal and Healthy School Climate," Jurnal Social Behavior and Personality, no 42 (Suppl.), pp. 93100, 2014.

[3] J.E. Tubbs and M. Garner, "The Impact of School Climate on School Outcomes". Jurnal College Teaching\&Learning, Vol 5, no 9, pp. 17-26, September 2008.

[4] A.J Macneil, Doris L. Prater, and Steve Busch, "The Effect of School Culture and Climate on Student Achievement". International Journal of Leadership in Education: Theory and Practice, vol 12, no 1, pp. 73-84., March 2009.

[5] J. Cohen, T. Pickeral, and M. McCloskey, "The Challenge of Assessing School Climate," Journal Educational Leadership, Vol 66, no 4, January 2009.

[6] C.A. Lehr and S.L. Christenson, Best Practices in Promoting a Positive School Climate, in A Thomas, and J. Grimes (Eds). Best Practices in School Psychology-IV, 2, pp. 924-948, 2002.
[7] S. Goldstein, A. Young, and C. Boyd, "Relational Aggression at School: Associations with School Safety and Social Climate," Journal Youth Adolescence, no 37, pp. 641-654. 2008.

[8] R.E. Durham, A. Bettencourt, and F. Connoly, Measuring School Climate; Using Existing Data Tools on Climate and Effectiveness to Inform School Organizational Health, Baltimore Education Research Consortium, 2014.

[9] M.C. Brault, M. Janosz, and I. Archambault, "Effects of School Composition and School Climate on Teacher Expextations of Students: A Multivel Analysis," Teaching and Teacher Education 44, pp. 148-159, 2014.

[10] J. Cohen, E. M. McCabe, N.M. Michelli, and T. Pickeral, "School Climate: Research, Policy, Practice, and Teacher Education," Teachers College Record, Vol 111, no 1, pp. 180-213, January 2009.

[11] G. Steffgen, S. Recchia and W.Viechbauer, "The Link Between School Climate and Violence in School: A Meta-Analytic Review, Journal Aggression and Violent Behavior, vol 18, issue 2, pp. 300-309, MarchApril 2013

[12] Y. Rich and E.P. Schachter, "High School Identity and Student Identify Development," Contemporary Educational Psychology, pp. 218-228, 2012.

[13] N.L. Popa, "Perception of School Climate and Parental Behaviours Among Romanian Students from Migrant Families," Procedia Social and Behavioral Sciences 47, pp. 1368-1373, 2012.

[14] M.L. Marshall, "Examining School Climate: Defining Factors and Educational Influences," [white paper, electronic version], Georgia State University Center for School Safety, School Climate and Classroom Management, (2004)

[15] J. Cohen, Jonathan, "Educator Effectiveness Series: Assessing School Climate; Q\&A with Jonathan Cohen," 2015.

[16] G.G. Bear, C. Gaskins, J. Blank, F.F Chen, "Delaware School Climate Survey-Student: Its Factor Structure, Concurrent Validity, and Reliability," Journal of School Psychology, vol 49, issue 2, pp. 157-174, April 2011.

[17] G. Cavrini, G. Chianese, B. Bocch and L. Dozza, "School Climate: Parents', Students', and Teachers' Perception," Procedia-Social and Behavioural Sciences 191, pp. 2044-2048, 2015.

[18] The Colorado Education Initiatives, Measuring School Climate; A Tool Kit for Districts and Schools, Colorado Department of Education, 2012.

[19] M.S. Sahrir, N.A. Alias, Z. Ismail and N.Osman, "Employing Design and Development Research (DDR) Approaches in The Design and Development of Online Arabic Vocabulary Learning Games Prototype," The Turkish Online Journal of Educational Technoclogy, vol 11 issue 2 pp.108-119, April 2012

[20] T.J. Ellis and Y. Levy, "A Guide for Novice Researchers: Design and Development Research Methods," Proceedings of Informing Science \& IT Education Conference (InSITE), 2010.

[21] D. Faster and D. Lopez, "School Climate Measurement and Analysis," National School Climate Center, 2013

[22] H. Beaudoin and G. Roberge, "Student Perceptions of School Climate and Lived Bullying Behaviours," Procedia-Social and Behavioral Sciences, vol 174, pp 321-330, February 2015.

[23] M.M. Mitchell and C.P. Bradshaw, "Examining Classroom Influences on Student Perception of School Climate: The Role of Classroom Management and Exclusionary Discipline Strategies," Journal of School Psychology vol, 51, p.p 599-610, October 2013.

[24] T.R Konold and D. Cornell, "Measurement and Stuctural Relations of An Authoritative School Climate Model: A Multi-Level Latent Variable Investigation,” Journal of School Psychology, vol 53, pp. 447-461, December 2015. 